\title{
FSN-NU 0014 \\ PROXIMATE COMPOSITION OF SOME COMMERCIAL FISH FEEDS SOLD IN NIGERIA
}

\author{
AYUBA V. O. AND E. K. IORKOHOL \\ Department of Fisheries and Aquaculture, University Of Agriculture Makurdi Nigeria
}

Copyright 2010, Fisheries Society of Nigeria.

This paper was prepared for presentation at the $25^{\text {th }}$ Annual International Conference and Exhibition in Administrative Staff College of Nigeria (ASCON), Topo-Badagry, Lagos, Nigeria, $25^{\text {th }}-29^{\text {th }}$ October, 2010.

This paper was selected for presentation by an FISON Program Committee following review of information contained in an abstract submitted by the author(s). Contents of the paper, as presented, have not been reviewed by the Fisheries Society of Nigeria and are subject to correction by the author(s). The material, as presented, does not necessarily reflect any position of the Fisheries Society of Nigeria, its officers, or members. Papers presented at FISON meetings are subject to publication review by Editorial Committees of the Fisheries Society of Nigeria. Electronic reproduction, distribution, or storage of any part of this paper for commercial purposes without the written consent of the Fisheries Society of Nigeria is prohibited. Permission to reproduce in print is restricted to an abstract of not more than 300 words; illustrations may not be copied. The abstract must contain conspicuous acknowledgement of where and by whom the paper was presented. Write Librarian, Fisheries Society of Nigeria (FISON), P O. Box 2607 Apapa Lagos.

\section{ABSTRACT}

A study was undertaken to analyse and compare with manufacturers' declaration the nutrient content of some feeds available in Nigeria through proximate analysis. The commercial fish feeds collected from the markets were Adolf Calyx, Coppens, Dizengoff and Durante. Proximate composition such as moisture, crude protein, crude lipid, ash, fibre and NFE (nitrogen free extract) were analysed. In general, there was variation between analysed and company declared nutrient contents of different feeds especially the protein and lipid content of the feeds. Apart from Adolf Calyx, all the analysed feeds had protein contents of above $40 \%$ which is good for catfish production as recommended by the manufacturer.

Keywords: Proximate composition, Commercial fishfeeds, Adolf Calyx, Coppens, Dizengoff, Durante.

\section{INTRODUCTION}

The nutrient balance of feed influences feed utilization and growth of fish. It is very essential to know the nutritional requirements particularly for protein, lipid and energy for optimum growth of a fish species as well as in formulating a balanced diet. Dietary protein and energy levels are known to influence the growth and body composition of fish (Lovell, 1989). Improper protein and energy levels in feed increases fish production cost and deteriorates water quality. Insufficient energy in diets causes protein waste due to the increase proportion of dietary protein used for energy and the produced ammonia can reduce the water quality (Phillips, 1972; Prather and Lovell, 1973 and Shyong et al., 1998). On the contrary, excessive energy in diets can lead to increased body lipid deposition and growth reduction because of lack of necessary nutrient for growth (Daniels and Robinson 1986, Van der Meer et al, 1997). From the economic point of view, feed cost appears to be one of the major constraints against the greater expansion of aquaculture. There is a paucity of information on the nutrient content of fish feed produced by different feed companies in Nigeria. There are also no reliable published information on chemical composition of commercial fish feed and feed ingredients in Nigeria. The farmers have to depend only on the existing information about the feed composition and growth performance that is given by the feed company. The government has no legal legislation and control over the feed components and feed quality. Also, there are no guidelines for the establishment of a new feed company. So there is a great possibility that the farmers will be deceived by the feed manufacturers. There is no monitoring by the government on the quality and nutrient content of the feeds produced by different feed manufacturers, even if there is a possibility to use unauthorized feed ingredients. So far, there has been dearth of information on evaluation of the nutrient content of feeds produced by commercial industries. Therefore, the 
present study investigates the nutrient composition of some commercial fish feeds available in Nigerian market and compares these values with those declared by the manufacturers.

\section{MATERIALS AND METHODS Collection and preparation of samples for analysis}

Samples of four commercially available feeds (2mm diameter) namely Adolf Calyx, Coppens, Dizengoff and Durante were collected from fish feed shops in Makurdi, Nigeria. The required amount of samples were finely ground by a laboratory grinding machine in University of Agriculture Makurdi Nigeria and kept in an airtight container for subsequent chemical analysis.

\section{Analytical methods}

The proximate composition of different commercial fish feeds were analyzed according to standard procedures given in Association of Official Analytical Chemists (AOAC, 1980). Triplicate samples of each commercial fish type were used to determine the following chemical compositions:

\section{Moisture}

Moisture was determined by keeping $2 \mathrm{~g}$ of the commercial fish feed samples in a thermostat oven at $105^{\circ} \mathrm{C}$ for 24 hours. The difference between the initial weight and the final weight gave the moisture content.

\section{Crude protein}

Samples (2 g) were digested in digestion unit (Digestor, model 2020) for 45 minutes. The digester was then distilled in distillation unit (Khjeltdah System, Distilling unit, model 1026). Finally, it was titrated with0.2 N HCL and crude protein was obtained by multiplying the total nitrogen by a conversion factor of 6.25 .

\section{Crude lipid}

Crude lipid was determined by extracting a weighed quantity of sample with acetone in Soxhlet Extraction Unit (model 1045).

\section{Ash}

Ash content was determined by igniting feed samples in a muffle furnace at $450^{\circ} \mathrm{C}$ overnight.

\section{Crude fibre}

Samples (2 g) were digested with $0.128 \mathrm{M}$ $\mathrm{H} 2 \mathrm{~S} 4$ with a few drops of octanol in digestion unit (Hot Extractor, Model-1017) for 30minutes. Filtering and washing with boiling water removed acid. Residue was boiled with $0.223 \mathrm{M} \mathrm{KOH}$ for 30 minutes, then washed in boiling water and acetone. The residue was dried in an oven at $130^{\circ} \mathrm{C}$ for 2 hours and ignited in muffle furnace at $500^{\circ} \mathrm{C}$ for 3 hours. The loss of weight represented the crude fibre.

\section{Nitrogen free extracts (NFE)}

NFE was calculated by subtracting the sum of moisture, crude protein, crude lipid, ash and crude fibre from 100 (Castell and Tiews, 1980).

Results obtained were subjected to statistical analysis using analysis of variance (ANOVA)

\section{RESULTS}

The results of proximate composition of different feeds analysed and manufacturers' declaration are shown in Tables 1 and 2 respectively.

\section{Moisture}

The analysed moisture contents varied between 6.87 to $8.10 \%$. Most of the collected feed samples contained lower moisture than the company declared moisture content.

\section{Crude protein}

The analysed crude protein contents were highest in Dizengoff (52.65\%) and lowest in Adolf Calyx (25.89\%). Coppens and Durante had crude protein contents of $43.75 \%$ each (Table 1) as compared to company's declarations of $42 \%, 45 \%, 53 \%$, $45 \%$ and $45 \%$. for Adolf Calyx, Coppens, Dizengoff and Durante. Even though there were differences between the analysed and company declared protein values they were not significantly different except for Adolf calyx feed $(\mathrm{P}>0.05)$. 


\section{Crude lipid}

The analysed crude lipid contents of different fish feeds varied considerably among the feed. The mean range of crude lipid was recorded as 10.78 (Durante) to14.77\% (Dizengoff) as shown in Table1.Similarly there were differences between the analysed and company declared crude lipid values even though they were not significantly different (except for Dizengoff ) from the company mentioned values $(\mathrm{P}>0.05)$.

Ash

The analysed ash contents of the collected commercial fish samples were in the range of $5.33 \%-9.45 \%$ while the manufacturer's declaration range was $5.1 \%-8.4 \%$.

\section{Crude fibre}

The analysed crude fibre contents of Adolf Calyx, Coppens, Dizengoff and Durantee were $12.73 \%, 7.43 \%, 3.20 \%$ and $5.27 \%$ (Table 1). Fibre contents of different feeds from all companies under study were significantly higher than the company declared maximum values $(\mathrm{P}>0.05)$.

\section{DISCUSSION}

Growth, health and reproduction of commercial fish and other aquatic animals are primarily dependent upon an adequate supply of nutrient, both in terms of quantity and quality, irrespective of the culture system in which they are grown. Therefore, supply of inputs (feeds, fertilizers etc) has to be ensured so that the nutrients and energy requirements of the species under cultivation are met and the production goals of the system are achieved (Hasan, 2001). Nowadays, commercial fish feeds are widely used to get more aquacultural production. Protein is the major growth promoting factor in feed. The protein requirement of commercial fish are influenced by various factors such as commercial fish size, water temperature, feeding rate, availability and quality of natural foods and overall digestible energy content of diet (Satoh, 2000; Wilson, 2000). The present study was undertaken to know the actual proximate composition and compare with the nutrient content declared by the different companies in Nigeria. From the chemical analysis, it was observed that most of the analysed data on crude protein were more or less similar to the company declared values. The crude protein content of most of the feeds of different commercial fish industries analysed was within the acceptable range recommended for commercial fish (NRC, 1983). Wilson (2000) reported that most of the commercial fish channel catfish feeds contain $32 \%$ crude protein. Boonyaratpalin (1988) estimated the protein requirement for tropical catfish to be $35-40 \%, 25-35 \%$ and $28-32 \%$ for fry, grow-out and broodstock.. Watanabe et al. (1990) observed that catfish production was increased through the use of high amounts of protein (35\% or more) in their diet and phase feeding may be more profitable. Lipids are primarily included in formulated diet to maximize their protein sparing effect (Hasan, 2001) by being a source of energy. The observed lipid values were in line with that of Cowey and Sargent (1979) who reported that in general, $10-20 \%$ of lipid in most freshwater fish diets gives optimal growth rates without producing an excessively fatty carcass. On the other hand, Wilson (2000) reported that lipid level in catfish feeds should be 5 to $6 \%$. Luquet (2000) also stated that dietary lipid levels of 5 to $6 \%$ are often used in tilapia diet.

All plant ingredients contain a certain amount of fibre. Fibre provides physical bulk to the feeds. A certain amount of fibre in feed permits better binding and moderates the passage of feed through the alimentary canal. However, it is not desirable to have a fibre content exceeding $8-12 \%$ in diets for fish, as the increase in fibre content would consequently result in the decrease of the quality of an unusable nutrient in the diet (De Silva and Anderson 1995). When the fibre content is excessive, it results to lower digestibility of nutrients. The analysed crude fibre content of all the 
diets under study were within the safe dietary limit for fish except for Adolf Calyx.

The research has revealed that even though there were variations between manufacturers' declaration and results obtained from the present study, the Crude protein contents of all the feeds, except Adolf Calyx, was above $40 \%$ and therefore suitable for catfish culture.

\section{REFERENCES}

AOAC. (1980). Official methods of analysis. Association of official analytical chemists, (ed. W. Horwitz) $13^{\text {th }}$ edition, Washington DC. 988 pp.

Boonyaratpalin, M. (1988). Catfish feed National Inland Fisheries Institute. Extension paper No. 528 (in Thai). Department of Fisheries, Bangkok, Thailand. 17 pp.

Castell, J.D. and K. Tiews. (eds.) (1980). Report on the EIFAC, IUNS and ICES working group on the standardization in fish nutrition Research. Hamburg, Federal Republic of Germany, 2123March, 1979. EIFAC Technical Paper, 26pp.

Cowey, C.B and J.R. Sargent. (1979). Nutrition. In: W. S. Hoar, D. J. Randall and J. R. Breet (Eds), Fish Physiology. Academic Press, New York. pp. 1-69.

De Silva, S.S. and T.A. Anderson. (1995). Fish nutrition in aquaculture. Chapman and Hall, 208 pp.

Hasan, M.R. (2001). Nutrition and feeding for sustainable aquaculture development in the third millennium. In: R.P. Subasinghe, P. Bueno, M.J. Phillips, C. Hough, S.E. McGladdery and J.R.Arthur (eds)Aquaculture in the third millennium. Technical proceedings of the conference on aquaculture in the third millennium Bangkok, Thailand, 20-25 February 2000,
NACA, Bangkok and FAO, Rome. pp 193-219.

Lovell, R.T. (1989). Nutrition and feeding of fish.Van Nostrand Reinhold, New York.114p.

Luquet, P. (2000). Tilapia, Oreochromis spp. In: R.P. Wilson (ed.), Handbook of nutrient requirement of finfish. pp. 169-180. CRC Press, Boca Raton Ann Arbor, Boston, London. 196p

NRC (National Research Council). (1983). Nutrients requirements of warm water fishes and shell-fishes. National Academy Press, Washington, DC, $102 \mathrm{pp}$.

Phillips, A. M. (1972). Calorie and energy requirements. In: J.E. Halver (Ed.) Fish Nutrition. pp. 2-29. Academic Press, New York, NY.

Prather, E.E. and R.T. Lovell (1973). Response of intensively fed channel catfish to diets containing various protein energy ratio. Proceedings of the 27th of the South-Eastern Association of Game and Fish Commissioner 27, 455-459.

Satoh, S. (2000). Common carp Cyprinus carpio. In: R.P.Wilson (Ed.)Handbook of nutrient requirement of finfish. pp. 55-68. CRC Press, Boca Raton Ann Arbor, Boston, London.196p.

Shyong, W.J., C.H. Huang and H.C. Chen (1998). Effects of dietary protein concentration on growth and muscle composition of juvenile. Aquaculture 167:35-42.

Van der Meer, M.B., J.E. Zamora and M.C. Verdegem. (1997). Effect of dietary lipid level on protein utilization and the size and proximate composition of body compartments of Colossoma macropomum (Cuvier). AquacultureResearch 28:405-417.

Wilson, R.P. (2000). Channel catfish, Ictalurus punctatus In: R.P. Wilson (Ed). Handbook of nutrient 
requirement of finfish. CRC Press,

London. pp. 35-53.

Boca Raton Ann Arbor, Boston,

Table 1: Mean Proximate Composition of Analysed Feeds

\begin{tabular}{lllll}
\hline $\begin{array}{l}\text { Proximate } \\
\text { composition }\end{array}$ & Coppens $\%$ & Dizengoff \% & Durante \% & Adolf Calyx \% \\
\hline Moisture & $8.10(0.27)$ & $8.62(0.087)$ & $7.20(0.06)$ & $6.87(0.11)$ \\
Ash & $9.44(0.12)$ & $5.33(0.02)$ & $7.23(0.17)$ & 7.45() 0.15 \\
Crude protein & $43.75(0.00)$ & $52.65(0.10)$ & $43.75(0.00)$ & $25.89(0.51)$ \\
Crude lipid & $11.93(0.13)$ & $14.77(0.05)$ & $10.75(0.06)$ & $12.50(0.04)$ \\
Crude fibre & $7.42(0.62)$ & $3.20(0.04)$ & 5.27() 0.05 & $12.73(0.10)$ \\
\hline
\end{tabular}

(Ayuba, V. O.and Iorkohol, E.K. laboratory analysis 2009)

Table 2: Manufacturers' Proximate Composition of Feeds

\begin{tabular}{lllll}
\hline $\begin{array}{l}\text { Proximate } \\
\text { composition }\end{array}$ & Coppens \% & Dizengoff \% & Durante \% & Adolf Calyx \% \\
\hline Moisture & & & & \\
Ash & 9.5 & 8.4 & 8.0 & 5.1 \\
Crude protein & 45 & 53 & 45 & 42 \\
Crude lipid & 12 & 14 & 11 & 13 \\
Crude fibre & 1.5 & 1.6 & 2.6 & 1.7 \\
\hline
\end{tabular}

